\title{
The use of social-networking sites in English language education: An exploratory study using SWOT analysis technique ${ }^{1}$ Sana Nazir Ahmed, ${ }^{2}$ Furrakh Abbas, ${ }^{3}$ Azhar Majeed Qureshi \\ ${ }^{1}$ School of English, Minhaj University Lahore \\ ${ }^{2}$ School of Languages, Civilization and Philosophy (SLCP), University Utara Malaysia \\ ${ }^{3}$ Assistant Professor, University of Education, Lahore Campus
}

\begin{abstract}
The global importance of English as the language of international communication needs no description. English has gained competitive edge and is considered a requirement in order to make progress in the global world. There is bulk of research dedicated to finding better means of learning and teaching English language. The current research aims at exploring the potential of using social networking sites for improving English language skills especially in the skill areas of reading and writing. The research proposes to analyze the opinion of the participants by using SWOT analysis technique. This technique dissects the themes from the data under strength, weakness, opportunity and threat in order to draw the picture of the potential of anything, In the current research, SWOT analysis technique was used to organize the data in the themes mentioned here. The study concludes that the use of social networking sites in English language education has marvelous potential as the students learn with ease of mind. The language is learnt without any affective filters like anxiety or lack of motivation. Though social media sites can be effective platforms, their use may also distract the language learners with all their misinformation, ungrammatical content, and artificial human interaction. The study implicates that there is need to formulate effective strategies for proximal advantage of the strengths and countering the weaknesses and threats in order to make the best of the opportunities provided by social media sites in English language education.
\end{abstract}

Keywords:

English language, writing skill, reading skill, social networking sites, SWOT Analysis Article

Received: 9 August 2020, Revised: 21 October 2020, Accepted: 10 December 2020

\section{INTRODUCTION}

Internet has been continuously changing the lifestyle of the people in different ways. With the extending universality of internet, the researchers and analysts from various fields continue believing it to be a zone of concentrate that should be explored further (Austin, 2002). Social networking is utilized through different electronic contraptions and battery-fueled gadgets like wireless, PC, tablets in this way various ways to deal with empower the people while giving their arrangements to others straightforwardly and efficiently. Internet is used for correspondence (Adams, 2002) as online life is now significant in sharing of data since empowers the customers to diverge from various sources. The use of internet through various modes has also been explored from the perspective of teaching especially with reference to English language teaching and learning in different ways (Rehman, Bashir,
Rehman, 2020; Barnlund, 2008). In this context, the application of google helps people share their scholarly articles and papers through a more proper channel than is the circumstance in other social networking administrations (Barnlund, 2008). Some major social network sites that have influenced the English language education are facebook, whatsapp, twitter etc.

Facebook messenger is the most commonly used social networking site to facilitate registered users to make profiles, transfer video and pictures, throw commenting on each other's profiles people stay in contact with family, friends and colleagues (Gardner, 2007). Facebook has about 1.86 billion monthly active users and it is the most accepted one-on-one communication website in the world, given the number of active client accounts (Barnlund, 2008). Messenger is linked with a Facebook site that is used as a messaging organization and programming application which 
is also connected with Facebook's online visit highlight (Safko \& Brake, 2009). WhatsApp is another commonly used freeware and mixed messaging application for mobile phone users. It is connected with the Internet to send text, make voice calls, one to one video calls; GIF, reports, recordings, pictures, voice notes and phone contacts to an unlimited number of customers utilizing standard cell numbers (Safko \& Brake, 2009). It also deals with a component called Status, which facilitates customers to move pictures and recordings to twenty four-hourslifetime (Barnlund, 2008). Twitter is also a form of social networking that is reckoned as a free microblogging administration, which enables enlisted individuals to communicate their thoughts through short posts called tweets. On Twitter, individuals can share their views through tweets and follow other persons' tweets by using various platforms and gadgets (Gardner, 2007).

Social networking is used for many purposes like sharing of information, socialization and exchange. The internet applications, contraptions, and regions had been orchestrated into increasingly broad perspectives concerning correspondence, joint exertion, and, expressly for "Social frameworks organization, print, Video,

Audio, Live casting, Photo sharing, Microblogging, Productivity applications, Gaming, Search, Rich site rundown, Mobile, and Interpersonal" (Safko \& Brake, 2009). Teachers have also started using Twitter, Blogs, Facebook, YouTube, or Flickr for the purpose of learning now. Therefore, the current study aims at exploring the potential of social networking sites in the English language education.

\section{LITERATURE REVIEW}

Socialization is an aspect of any social group and is important and valuable, it also has drawbacks (Abbas, Farid, Iqbal \& Parveen, 2020). Socialization isn't a worth nonpartisan procedure since it is constantly guided by the predominant standards, qualities, presumptions, and convictions of a given society (Hursen, \& Ceker,
2012). The importance of surfing social networks in the getting know praocedure its effectiveness or enhancing scholar's overall performance in reading and writing talent. On the net, college students engage in different activities and many of them are likely addicted (Kolek \& Saunders, 2008). The attraction of social media on the internet may be a reason for the challenge, generally, a large number of college students spend their time on-line.

Students who are undergraduates waste the time on social sites such as Facebook, Twitter, and WhatsApp through smartphones which can be now spreading among youth. Students who are socially addicted cannot pass their time without checking and updating their statuses and other different activities (Gardner, 2007). High faculty college learners use those websites as utensils to gather statistics and sources for graduation direction and better opportunity plans. For instance, the students looking for colleges can visit profiles of that college's students to view the study journal of beyond college students to decide either the university could be a great or not (Ellis, 2007). Selwyn (2009) marked that whereas the use of social sites such as Facebook is spreading fast among the students so it could be beneficial for the educational platform and not showed harm towards students. In Asia, about 194 million users are using this site. It is about people using Facebook and social sites as their means of communication. It is the choice of the young generation and thus raises the question of how does it could be beneficial for a learner to acquire a second language (Clyne \& Sharifian, 2008). To develop writing skills studies explore the use of an online platform like discussion and blogs (Shih, 2011).

The feature of web technology such as YouTube videos, blogs and online forums to raise creative writing can be used in the language classroom (Uzunboylu, Bicen \& Cavus, 2011). Yet, the users of Facebook and social media are growing day by day. Guiffrida (2005) stated that through 
technologies learners become more analytical, sharp and familiar with writing online which obliquely helps them in improving their written task. He further stated that Facebook is a productive means to boost students 'writing skills because it gives a path for students to think about ideas and share their various views. Lee \& Woods (2010) inaugurated that Facebook is a useful way for the students to increase, and reinforce learning of the English language. They said that social sites are formed for students because they are motivated to write their ideas and views points freely. Shih (2011) shared that students with less confidence and who are with high anxiety can actively participate in language tasks and thus felt less afraid than the students who are with better skills. It also suggested that online practice allowed the instructor and students to have more interaction.

It is said that the electronic life has made the language learning logically supportive through various affiliations and correspondence openings on the web (Stutzman, 2006). The adolescents' language or language is honestly auxiliary to the first experience with their condition. Social interactionists' idea, likewise, imparts that the verifying of a language happens when youths regularly collaborate with more language able adults through physical, phonetic, abstract and social factors (Reinhardt \& Zander, 2011). One repression of this theory is that when an individual imparts and gets off-base and inappropriate sort of language from others, in fact, or online life. With more than 175 million all-inclusive customers, Facebook, for one, is unmistakably one of the individuals to individual correspondence regions that partners people the world over and gives a space to the joint effort and sharing of culture, data, and language (Harrison \& Thomas, 2009).

The possibility of social affiliation, yet again, is the approach that explains the subject of language learning in long-range casual correspondence areas. In the viewpoint on social interaction, the activity of "intercession" is critical in the improvement of human learning (Fraser, 2000). Mostly the students face the problem when they write something in English as English is their second language (Rana, Bashir \& Abbas, 2020) and exposure toward writing English is limited (Clyne \& Sharifian, 2008). Many researchers have shown that the students feel fear while writing because they are doubtful and have no clear ideas about the language (Steckman \& Andrews, 2017). Students who are good at writing cannot produce a comprehensible piece of writing in L2. Generally, the learner only writes to satisfy their public and educational examination requirement (Shams \& Iqbal, 2020). As technology is flourishing, teachers can use different methods so the process of teaching and learning could be beneficial (Guiffrida, 2005).

\section{METHODOLOGY}

For this present research, a SWOT analysis technique was used to discover the strengths, weaknesses, opportunities and threats of the social networking sites with reference to English language education. It is an analysis tool that is usually used in business administrations and organizations, and it was developed because of its practicality and effectiveness (Wright \& Pickton, 1998). The said approach was considered to be most appropriate for this research as the model is exploratory and the words that make up the construct of SWOT are the integral aspect of the current study. The population included English language students which were considered to be the direct users of the social media and the key people in learning the English language from the different educational institutions (Qadri \& Akram, 2020). Interview was the primary method of data collection for this research as there were thirty students interviewed about their views about English learning by using social networking sites. The participants were interviewed individually and their views about the strengths, weaknesses, opportunities and threats were sought. The convenience sampling in quantitative research was used in this study and students were selected for 
their capability and experience in social media to gain insight in the field of English language learning. The data was collected from the sample of thirty participants selected from universities: Education University Lahore (Bank Road) abbreviated as UE, Gulberg College for women University abbreviated as GCW and Kinnaird College for Women University abbreviated as KCWU. The data was analyzed by using the SWOT analysis matrix which focuses on organizing the themes in terms of strengths, weaknesses, opportunities and threats. This technique has been borrowed from the discipline of management and applied in exploring the potential of social media sites in the current study. The quotations of the participants have been coded to identify the participants and the demographic information used for coding the participants is related to 1) status of participant as student, 2) gender as male or female, 3 ) age of the participants, 4) the university they belonged to and 5) the background of the participant as rural or urban.

\section{INTERPRETATION AND ANALYSIS OF DATA}

The current research aims at exploring the use of social networking sites for the purpose of English language education. In order to organize and analyze the data, SWOT analysis technique was used which aims at dividing themes in terms of strengths, weaknesses, opportunities and threats. These themes are being presented in the same sequence here:

\section{Strengths}

English proficiency and learning style differ from student to student and some students find it easier to understand the concept by reading a textbook, while others prefer a verbal explanation. Similarly, people may vary in how they most effectively demonstrate their understanding of English learning skills in social networking. The participants have determined the strengths that how social media positively influences English language learning. They said that web-based social networking gives complete understanding for English language students where the students are grabbing the language in a progressively regular manner through the presentation of the correspondence, association and cooperation of the social networking, regardless of whether they are sending messages, posting on Facebook, Twitter, or Instagram, or they are playing webbased games, they get an opportunity to work and to utilize the English language skill.

The result shows that internet-based life is fixed in the lives of the students in this cutting edge world, and English language skill is simpler to access a print-rich condition where the learning English is explicitly encouraged. This study has revealed that social media have several strengths that positively reinforce or boost English language learning among their users. The students get to use the language in any social media through interaction, communication, connection and sharing of knowledge. Another strong link between social media and language learning is the fact that social media or any related technologies are deeply embedded in the modern world and culture.

"The role of social networking is an allaccessible thing and without any problem, all the data is received through the hotspot for language learning. There is no convincing reason behind the fact that the students are to acquire an English guide and foundations without any cost." S/M/26/UE/Urban

" In social networking, there are a lot of articulations, slang, or abbreviations that we can never gain from our coursebooks but social networking is helping us to use the language more normally and effectively." $S / F / 24 / U E / R B$

" For English, online networking is inserted in the cutting edge culture. The youngsters especially these days can use the utilization of Facebook, YouTube recordings, and games for instructive and correspondence purposes. With the 
availability of this innovative unique and fast technology, language learning becomes more securing and also it is constantly conceivable." S/M/29/GCW/Urban

"English language students improve their relational abilities through web-based social networking connection in a wide premise effectively." $S / F / 23 / G C W /$ Rural

"With the use of social networking, my very own understanding is that I've become captivated with Tech as, I have built up a jargon that not many people know about it, I was very timid and embarrassed when I was going to begin conversations or questions to various persons because of my poor and weak jargon before using a social network but now, I have found myself perfect with the varioustypesofonlinelife."

\section{S/F/26/KCWU/Urban}

\section{Weaknesses}

Unluckily, in Pakistan, the students do not have much expertise on the internet which can be a stumbling blockage for them to take the advantage of the availability of online social networking in the English language. A wide range of data is accessible in web-based life like language fledglings generally get phony news, disgusting articulations, and even ungrammatical English writings. These unfiltered language data sources are influencing one's language learning, also give the realization that how to concentrate on the right sort of data. These insecure perspectives are significantly present in a viable correspondence process. Besides that, if the individuals invest their energy in online social networking life, the more they will less interact with face to face dealing. In light of their developing ubiquity, the internet-based life deeply influences the language with its linguistic and grammatical imperfections which are recorded as a hard copy. Additionally, an individual's mind depends on how quickly he/she ought to have the option to post or share something; they don't have the opportunity to keep an eye on their spelling and sentence structure as well. The absence of real human interaction on computer screens also took the disadvantage of social media and the modern way of communication has hindered the social media users' writing skills.

"With the usage of social networking, lie conversation in online communication shapes one's perspective on the truth. For example, the pretentious news which is being reinforced in a long-range casual communication site can be seen to be valid by a common newcomer."

S/M/27/UE/Urban

"The absence of a real authentic language turns off the connection of truth, fraud actions prevail and confusing language influenced the mind of the students. The family connections through internet usage ended up and personal relations are changed because of social networking correspondence." S/F/24/GCW/Urban

"Now a day, the rise of the web-based life is destroying the lives of youth and, additionally it brought the exploitation of shortened words, content information, false images, and web fake languages among the students. The students are communicating through this cutting edge arrangement of social networking, which affects less or more on the students' academic writings. The most negative part of this digitalization world, the students are using more slang and alternate ways to maintainsocialstatus."

\section{S/M/27/KCWU/Urban}

\section{Opportunities}

Social networking cleared the route for the direction of online instruction or classes because language students are probably going to imitate the style and compose the language through video web journals, tweets, Facebook posts, Instagram subtitles, web recordings, music sounds and 
recordings. For them, online networking gives chances to language students to communicate with specialists from all the fields and get the ideal data that they look for. In the $21^{\text {st }}$ century, social networking provides some means of learning and it is comprehended to assume an extraordinary job in advancing the $21^{\text {st }}$-century abilities. Social abilities, among different skills like coordinated effort, inventiveness, and basic reasoning, is viewed as a significant competency that a student must have the option to flourish in this cutting edge society. It is the vehicle for the students which exceptionally urges their interest to cooperate, share the information, ability to work together, practice the imagination, and speak with other individuals. Even though it creates the impression that this age gets familiar with any innovation at incredible simplicity and speed, regardless they need directions from grown-ups or specialists with regards to exactness, substance, and legitimacy of data. Students are sure that online life becomes the eventual fate of correspondence, training language students and also concerning the adjustments in innovation. Through these sites, people can have an opportunity to get access to native speakers of English on a wider basis.

"The role of learning through social networking can be effective and fruitful as compare with eye to eye learning whenever it is organized well." S/F/24/EU/Urban

"For students, there is much open door to build up an association with English-

talking or English-rehearsing to individuals around the globe for social cooperation or connections." S/M/29/UE/Rural

"The importance of social media also subtly provides a $21^{\mathrm{st}}$-century learning experience alongside relevant skills like communication,creativity,critical thinking, and collaboration."
"The future of learning through social media is also secured that technology is constantly innovating and it will always be a creative thing for the future students." S/F/27/KCWU/Rural

\section{Threats}

The people proved that this present age's commitment to innovation, specifically with the internet-based life, is the reason to divert the mind of the students from the actual goal. The skilled individuals do perform multiple tasks and do multiple things simultaneously in the media; they are in general wasting their time on irrelevant things. It is also seen that an excess of time spent by the people in informal communication locales, internet games, watching video blogs, and other rambling stuff on online networks which cause of an interruption in quality time of the students who should have spent on their studies. These interruptions brought by online life are enormous dangers in the learning and soundness of their users. Social networking and internet-based life have become the places where the various types of societies, foundations, and language people meet; miscommunication is in some cases unavoidable. The various dialects other than English can also intrude the language learning and danger for its securing. With the passage of time and advancement in social media, the language meanings of the words become erroneous and they do not have any longer authentic process for the same meaning in the English language, there are a lot of wrong words/jargons, ungrammatical lexis usage, and the students of the language which are generally grasped such arrangement of language and acknowledge them regardless of their erroneousness. In learning the English language, if it is not used properly, the social media would disrupt the language of the learners and be exposed to unhealthy posts and content, the learners waste their time unlike when they are into more irrelevant materials. The different languages are spoken by the people in social media which can also interfere in English language learning and 
can build a barrier in communication. The rise of internet slang and subverting languages also play as threats in language learning and can be dangerous if not properly addressed by educators.

"It is observed that students discovered the shortcomings, and dangers of web-based social networking in English language

learningbecomemoreserious."

\section{S/F/26/GCWU/Urban}

"The dangers as indicated by the information are the constant abounding of slang usage and undermining language on online life." S/F/24/EU/Urban

"The correct usage of online life among students can be ground-breaking with regards to English language learning. PCs, innovation, and web-based life are all risky; children can undoubtedly get an entrance to them and learn those things which are harmful to their body and mind". S/M/28/KCWU/Rural

To maximize the use of social media in learning the English language learning involves exploiting the strengths, opportunities, and justifying as much as possible all their weaknesses and threats. It can be done by giving the guided activities which are using in these sites, programs, and apps. Since the learners intuitively pick up media literacy, social networking sites can also be incorporated in the classroom. Since the educators are the leaders in the instructing of the English language, it appears to be ideal to keep themselves aware of everything of every one of these advances and internet-based life. Having webbased life, skillful language educators will be of an incredible part of flexibility in instructing and directing the language students. To comprehend what destinations the students are into, knowing their language, realizing how to manage them, and realizing how to utilize these media in language guidance which are interesting points in teaching the present age.

DISCUSSION AND CONCLUSION
The study concludes that the use of social networking sites in English language education has marvelous potential. Social media provides a novel and easily accessible resource for English language education as it facilitates the learners by providing them autonomy to control their learning. Since most of the students are already engaged in the use of social media so the use of social networking sites does not burden the students and they learn with ease of mind. The strengths and opportunities of the use of social networking sites in English language education is best reflected in the fact that the language is learnt in naturalistic mode and without any affective filters like anxiety or lack of motivation. Since the study aimed at presenting a comprehensive SWOT analysis of the use of social networking sites for English language education, some weaknesses and threats were also noticed by the participants of the study. The study concludes that though social media sites can be effective platforms for providing latest information and English language input, it may also distract the language learners with all their misinformation, ungrammatical content, and artificial human interaction. The study implicates that the use of social networking sites provides a potential resource as the tradition modes of language education through books and text material stand no comparison. Therefore, the learners prefer to learn English language through these sites without boredom as this emerging mode of education is more natural and assimilative in nature. The study also implicates that there is need to conduct more research from the viewpoint of different stakeholders to maximize the learning benefits. The effective formulation of strategies is required for proximal advantage of the strengths and on the other hand, there is need to counter the weaknesses and threats in order to make the best of the opportunities provided by social media sites in English language education.

\section{REFERENCES}


[1] Abbas, F., Farid, M. F., Iqbal, A. \& Parveen, S. (2020) Impact of using newspapers reading on English reading proficiency: A study of Pakistani university students. International Journal of Innovation, Creativity and Change. 14 (10), 223-232.

[2] Abbas, F., Jalil, M. K., Zaki, H. N. \& Irfan, F. (2020). Implicit measure of language attitude: study of Punjabi native speakers by using matched guise technique. International Journal of Innovation, Creativity and Change, 13 (1), 194-206.

[3] Adams, K. A. (2002). What Colleges and Universities Want in New Faculty. Preparing Future Faculty Occasional Paper Series. Association of American Colleges \& Universities, 1818 R Street, NW, Washington, DC 20009.

[4] Antony, J. S., \& Taylor, E. (2004). Theories and strategies of academic career socialization: Improving paths to the professoriate for black graduate students. Paths to the professoriate: Strategies for enriching the preparation of future faculty, 92-114.

[5] Arnold, N., Ducate, L., Lomicka, L., \& Lord, G. (2009). Assessing online collaboration among language teachers: A cross-institutional case study. Journal of Interactive Online Learning.

[6] Austin, A. E. (2002). Preparing the next generation of faculty: Graduate school as socialization to the academic career. The journal of higher education, 73(1), 94-122.

[7] Barnlund, D. C. (2008). A transactional model of communication. Communication theory, 2, 47-57.

[8] Berberet, J. (2008). Perceptions of earlycareer faculty: Managing the transition from graduate school to a professional career. New York, NY: TIAA-CREF Institute.

[9] Black, R. W. (2005). Access and affiliation: The literacy and composition practices of English-language learners in an online fanfiction community. Journal of Adolescent \& adult literacy, 49(2), 118-128.

[10] Bo-Kristensen, M., Ankerstjerne, N. O., Neutzsky-Wulff, C., \& Schelde, H. (2009). Mobile City and Language Guides--New Links between Formal and Informal Learning Environments. Electronic Journal of E-learning, 7(2), 85-92.

[11] Boogart, M. R. V., \& Robert, M. (2006). Uncovering the social impacts of Facebook on a college campus (Doctoral dissertation, Kansas State University).

[12] Bosch, T. E. (2009). Using online social networking for teaching and learning: Facebook uses at the University of Cape Town. Communication: South African Journal for Communication Theory and Research, 35(2), 185-200.

[13] Cain, J. (2008). Online social networking issues within academia and pharmacy education. American journal of pharmaceutical education, 72(1).

[14] Cheung, C. M., Chiu, P. Y., \& Lee, M. K. (2011). Online social networks: Why do students use Facebook?. Computers in human behavior, 27(4), 1337-1343.

[15] Clyne, M., \& Sharifian, F. (2008). English as an international language: Challenges and possibilities. Australian Review of Applied Linguistics, 31(3), 28-1

[16] Crossley, S. A., Louwerse, M. M., McCarthy, P. M., \& McNamara, D. S. (2007). A linguistic analysis of simplified and authentic texts. The Modern Language Journal, 91(1), 15-30.

[17] Crystal, D. (2012). Think on my words: Exploring Shakespeare's language. Cambridge University Press.

[18] Duff, P. A. (2002). The discursive co- construction of knowledge, identity, and difference: An ethnography of communication in the high school mainstream. Applied linguistics, 23(3), 289322. 
[19] Edwards-Groves, C. (2012). Interactive creative technologies: Changing learning practices and pedagogies in the writing classroom. Australian Journal of Language and Literacy, The, 35(1), 99.

[20] Ellis, R. (1997). SLA Research and Language Teaching. Oxford University Press, 198 Madison Avenue, New York, NY 10016-4314.

[21] Fernàndez, C., \& Gil-Rodríguez, E. P. (2011). Facebook as a collaborative platform in higher education: The case study of the Universitat oberta de Catalunya. In Technology-Enhanced Systems and Tools for Collaborative Learning Scaffolding (pp. 2746). Springer, Berlin, Heidelberg.

[22] Feuerstein, R., Feuerstein, R. S., Falik, L. H., \& Rand, Y. (2003). The Dynamic Assessment of Cognitive Functions: The Learning Propensity Assessment Device, Theory, Instruments, Techniques.

[23] Fraser, H. (2000). Coordinating improvements in pronunciation teaching for adult learners of English as a second language. DETYA (ANTA Innovative project).

[24] Fries-Britt, S. L., Younger, T. K., \& Hall, W. D. (2010). Lessons from high-achieving students of color in physics. New Directions for Institutional
Research, 20IO(148), 75-83.

[25] Gardner, R. C. (2007). Motivation and second language acquisition.

[26] Gemmill, E. L., \& Peterson, M. (2006). Technology use among college students:

Implications for student affairs professionals. Journal of Student Affairs Research and Practice, 43(2), 482-502.

[27] Golder, S. A., Wilkinson, D. M., \& Huberman, B. A. (2007). Rhythms of social interaction: Messaging within a massive online network. In Communities and technologies 2007 (pp. 41-66). Springer, London.
[28] Grosseck, G., Bran, R., \& Tiru, L. (2011). Dear teacher, what should I write on my wall? A case study on academic uses of Facebook. Procedia-Social and Behavioral Sciences, 15, 1425-1430.

[29] Guiffrida, D. (2005). Othermothering as a framework for understanding African American students' definitions of studentcentered faculty. The Journal of Higher Education, 76(6), 701-723.

[30] Harrison, R., \& Thomas, M. (2009). Identity in online communities: Social networking sites and language learning. International Journal of Emerging Technologies and Society, 7(2), 109-124.

[31] Hursen, C., \& Ceker, E. (2012). Evaluating teacher competencies in using new instructional technologies. International Journal of Learning and Teaching (IJLT), 4(1), 1-13.

[32] Jung, J. J., \& Kazienko, P. (2012). Understanding Online Social Networking Services. J. UCS, 18(8), 970-972.

[33] Kaplan, A. M., \& Haenlein, M. (2011). Two hearts in three-quarter time: How to waltz the social media/viral marketing dance. Business horizons, 54(3), 253-263.

[34] Kolek, E. A., \& Saunders, D. (2008). Online disclosure: An empirical examination of undergraduate Facebook profiles. Journal of Student Affairs Research and Practice, 45(1), 1-25.

[35] Krashen, S. D. (1985). Inquiries \& insights: second language teaching: immersion \& bilingual education, literacy. Alemany Press.

[36] Lee, S. E., \& Woods, K. J. (2010). Using contemporary topics and Internet resources to stimulate student-centered learning. Australasian Journal of Educational Technology, 26(6)

[37] Malerba, M. L. (2011, July). Social networking is second language learning. In Proceedings of PLE Conference (pp. 1-6). 
[38] Malik, M. A. Abbas, F. \& Noreen, K. (2020) A comparative study of acoustic cues of Punjabi velar plosives in Majhi and Lehandi. Hamdard Islamicus, 43 (2), 517-526.

[39] Maloney, E. J. (2007). Technology: What Web 2.0 can teach us about learning In the Chronicle of Higher Education,(p. B26).

[40] McConnell, D. (2000). Implementing computer supported cooperative learning. Psychology Press.

[41] Pickton, D. W., \& Wright, S. (1998). What's swot in strategic analysis?. Strategic change, 7(2), 101-109.

[42] Qadri, M. R. \& Akram, K. (2020). A study to investigate the role of Youtube in language development of toddlers. Competitive Educational Research Journal (CERJ) 1(1), 1-13.

[43] Rana, A.M.K, Bashir, I. \& Abbas, F. (2020). English for future employment: The perception of Pakistani academia. Hamdard Islamicus, 43 (2), 215-223.

[44] Raudenbush, S. W., \& Bryk, A. S. (2002). Hierarchicallinearmodels: Applications and data analysis methods (Vol. 1). sage.

[45] Rehman, Z. ur R., Bashir, I., \& Rehman, A. R. ur. (2020). An exploration of teachers' code switching: The case of English language classroom. Competitive Social Science Research Journal, 1(2), 54-71.

Retrieved from https://cssrjournal.com/ojs/index.php/cssrjou $\underline{\mathrm{rnal} / \mathrm{article} / \mathrm{view} / 19}$

[46] Reinhardt, J., \& Zander, V. (2011). Social networking in an intensive English program classroom: A language socialization perspective. Calico Journal, 28(2), 326-344.

[47] Reutzel, D. R., Brandt, L., Fawson, P. C., \& Jones, C. D. (2014). Exploration of the Consortium on Reading Excellence Phonics Survey: An Instrument for Assessing Primary-GradeStudents'Phonics
Knowledge. the elementary school journal, 115(1), 49-72.

[48] Safko, L., \& Brake, D. K. (2009). The social media bible: Tactics, tools, and strategies for business success. Hoboken: Wiley John \& Sons.

[49] Selwyn, N. (2009). Face working: exploring suberses use of Facebook. Learning, media and technology, 34(2), 157-174.

[50] Shams, J. A., \& Iqbal, M. Z. (2020). An investigation of prospective teachers' perceptionsaboutresearchtraining environment at university level in Pakistan. Competitive Social Science Research Journal, 1(1), 1-13. Retrieved from

https://cssrjournal.com/ojs/index.php/cssrjou rnal/article/view/20

[51] Sheldon, P. (2008). The relationship between unwillingness-to-communicate and students' Facebook use. Journal of Media Psychology, 20(2), 67-75.

[52] Shih, R. C. (2011). Can Web 2.0 technology assist college students in learning English writing? Integrating Facebook and peer assessment with blended learning. Australasian Journal of Educational Technology, 27(5).

[53] Shih, R. C. (2013). Effect of using Facebook to assist English for business communication course instruction. Turkish Online Journal of Educational TechnologyTOJET, 12(1), 52-59.

[54] Sointu, E. T., Savolainen, H., Lambert, M. C., Lappalainen, K., \& Epstein, M. H. (2014). Behavioral and emotional strengthbased assessment of Finnish elementary students: Psychometrics of the BERS2. European journal of psychology of education, 29(1), 1-19.

[55] Steckman, L. M., \& Andrews, M. J. (Eds.). (2017). Online around the world: A 
geographic encyclopedia of the Internet, social media, and mobile apps. ABC-CLIO.

[56] Stutzman, F. (2006). An evaluation of identity-sharing behavior in social network communities. Journal of the International Digital Media and Arts Association, 3(1), 10-18.

[57] Stutzman, F. (2006). Student life on Facebook. online], http://www. ibiblio. org/Fred/Facebook/stutzman_fbook. pdf (Retrieved June 3, 2008).

[58] Tauqir, T. \& Akram, K. (2020). Linguistic analysis of language used in placards observed during Aurat March 2020. Competitive Linguistic Research Journal (CLRJ), 1(1), 1-16.

[59] Thorne, S. L., Black, R. W., \& Sykes, J. M. (2009). Second language use, socialization, and learning in Internet interest communities and online gaming. The modern language journal, 93, 802-821.

[60] Udosen, A. E. (2005). Rethinking classroom evaluation: A case study of English language teachers' assessment practices in Uyo senatorial district of Akwa Ibom state. Journal of world council for curriculum and instruction, 5(1), 94-104.

[61] Uzunboylu, H., Bicen, H., \& Cavus, N. (2011). The efficient virtual learning environment: A case study of web 2.0 tools and Windows live spaces. Computers \& Education, 56(3), 720-726.

[62] Walaski, P. (2013). Social media: Powerful tools for SH\&E professionals. Professional Safety, 58(04), 40-49.

[63] Yuen, S. C. Y., \& Yuen, P. (2008, November). Social networks in education. In E-learn: World conference on e-learning in corporate, government, healthcare, and higher education (pp. 1408-1412).
Association for the Advancement of Computing in Education (AACE).

[64] Ziegler, S. G. (2007). The Education of Generation M. Learning, Media and Technology, 32(1), 69-81. 